\title{
An exploration of the impact of training on community governance; a case study of communities affected by Bui dam construction, Ghana
}

\begin{abstract}
This paper contributes to the discussions on community governance by focusing on thirteen communities near Bui dam and Bui National Park in Ghana. This paper seeks to address the impacts of dam construction and related resettlements through analysis of community competence training. The paper assesses the impacts of Bui dam and resettlement on community leadership, the impact of Bui Dam construction on traditional leadership, and the impact of Bui Dam resettled communities on the management of Bui National Park. For each of these questions, further analysis was undertaken to assess the role of resettlement, ethnicity, age, livelihoods, and gender. Data was gathered through multiple methods. In the design of a survey, questionnaires were administered to 339 respondents across the thirteen communities, document analysis and interviews were conducted. Interviews were conducted for 24 key informants and used for data collection. ANOVA and Scheffe test scores were used to assess impacts of Bui dam and resettlement. The paper resolved that people perceive training opportunities in community leadership to have failed to meet the core needs and focus of the impacted communities. The number of training modules were few, and the modules failed to focus on the core skills domain of traditional leadership, management of Bui National Park, and structures to build the livelihood needs of communities. Training opportunities did not provide adequate inputs to explore opportunities in areas such as traditional leadership, and management of Bui National Park. Ethnicity (Nafana, Ewe, and Mo) and relocate were perceived to provide weak influence on community leadership skills and options available to communities to address the impacts of dam construction and resettlement. Gender and age do not predict community leadership. The need to provide practical hands-on training for communities in the phase of the construction of a hydro dam is critical in providing better coping strategies to deal with changes in traditional leadership.
\end{abstract}

Keywords: dam, training, governance, community, livelihood, ethnicity, age, gender, resettlement
Volume I Issue 2 - 2017

\author{
Jones Lewis Arthur \\ Department of Secretaryship and Management Studies, Sunyan \\ Technical University, Ghana
}

Correspondence: Jones Lewis Arthur, Department of Secretaryship and Management Studies, Sunyani Technical University, PO Box 206, Sunyani-Ghana, Ghana, Tel +233209205506, Email jonesarthur2002@yahoo.co.uk

Received: March 05, 2017 | Published: August 24, 2017

\section{Introduction and overview}

The struggle to address community livelihood challenges persists in many developing countries. ${ }^{1-3}$ However, attempts to use training to build community relationships and reduce dam impacts on community relationships is a complex undertaking. One critical but not well understood issue is the response of communities to training that impact on community and traditional leadership in the phase of the impacts shocks such as hunger, drought, floods, and construction of dams and associated resettlements that impact on community livelihoods. This paper explores these issues through a study of Bui dam in Ghana, and the influence of the dam on traditional leadership. Dam construction can contribute to socio-economic development in many developing countries. ${ }^{4-6}$ For example, dams can increase energy access, control floods, and increase infrastructural development. ${ }^{6,7}$ However, dams can undermine the social and ecological integrity of community resources, displace and destabilize communities, and fracture relationships and social systems that form the foundation for effective governance arrangements. ${ }^{8-11}$ Dams can also adversely affect livelihoods and the socio-economic wellbeing of people whose assets are acquired, as well as the communities they live in. ${ }^{12}$ For example, the construction of Arase dam, Japan disrupted feeding routes of fish and diminished fish catch. ${ }^{13}$ The Don Sahong Dam in Cambodia jeopardized migratory routes of fish, undermined food security and livelihoods of millions of people. ${ }^{14}$

Dam related resettlements have led to loss of land, legal authority over land, community support for members, and cultural and traditional healing systems. ${ }^{15,16}$ Dams and resettlements have impacted governance in nearby communities. For example, the application of international laws over indigenous rights resulted in the loss of the voice of the people of San Kaputura (a resettlement communities near Etosha National Park), and led to a dependence on the government. ${ }^{16,17}$ In the cases of dam impacted communities, the voices of the displaced are rarely heard. ${ }^{16}$ Some studies have argued that the development of training that impact on community competence can improve community leadership and relationship and support the capacity of communities to cope with socio-ecological changes such as dams and associated resettlements through (1) improvement in knowledge about hazard impacts, (2) skills training and development, (3) livelihood enhancement programmes, and (4) development and improvements in community assets..$^{1,18,19}$ Wallerstein ${ }^{20}$ argues that skills training is central to community empowerment as well as addressing the challenges of powerlessness among people. Providing training in community intervention areas such as community health care can result in substantial reductions in child mortality through the management of ill children in Ghana. ${ }^{21}$ Similarly, skills training in indigenous 
conservation practices were shown to support effective hunter-gather traditions for resettled communities in Nyae Nyae Conservancy, Botswana ${ }^{16}$ However, knowledge of hazards and consequences alone does not exercise significant influence on preparedness. ${ }^{22,23}$ The ability to make the right decisions and a person's ability to make, and act on, his or her own decisions has provided some important haulmarks for developing the competence of some communities whose livelihoods have been undermined by shocks. ${ }^{24-27}$ For example, the application of proper decision making that involve local level management with a colloborative governmental support is important to address conflicts in fisheries in the long term. ${ }^{9}$

In other situations of shocks that impact livelihoods, some communities have applied effective skills development programmes to achieve successful conservation plans; by applying knowledge in indigenous conservation practices, ${ }^{1,28,29}$ and effective participation in governance of PAs to cope with socio-ecological changes such as species loss, poverty, and loss of community livelihoods and assets. ${ }^{30-33} \mathrm{~A}$ case is made by Robinson et al. ${ }^{34}$ that, Community Resource Management Area (CREMA) framework is instrumental in promoting conservation to support livelihood objectives. In Ghana, a CREMA is organized by a community, individuals or in a group to seek the right to manage resource in an area such as, the Kunlog CREMA that protects the Bushbuck in Jilinkon, Ghana. ${ }^{34}$

Communities with enhanced skills training in community leadership are able to contribute to the management of nearby protected areas by contributing to management authority, decision making, responsibility and ownership of Pas., ${ }^{9,35-37}$ Also, knowledge about natural resources, culture and skills in problem solving led to some conservation successes in Ghana; as illustrated by the recognition of traditional forms of conservation, and the completion of an inventory of 5000 sacred groves. Another example is the support of community enforcement that reduced poaching and forest destruction in Kakum Conservation Area. ${ }^{1,9,33,35-37}$ A number of other variables are thought to sometimes influence community efforts to develop and improve competence in community leadership. Regarding gender Greenburg et al. ${ }^{38}$ argue that boys are more responsive to negative influences of the neighbourhood, and therefore more vulnerable to their environment. Gender and social skills measured by performance on a role play, shows that being a male in the United States is identified as a risk factor for maladjustment during childhood. ${ }^{39}$ Men use more problemfocused coping than women at work and in situations having to be accepted and requiring more information but, not for emotion-focused coping. ${ }^{40}$ Abukari \& Laser $^{41}$ argue that the Ghanaian youth often experience minimal early learning opportunites but, females are more negatively impacted through sex discrinimation, and other forms of discrimination in education. In most cases, such discrimination comparatively predispose females to significant riskes for dropping out of school and also reduces their chances to attain postsecondary education. Other studies have indicated that gender contributes significantly to explaining the competence of people who act as activists in communities. ${ }^{42}$ For example, there is the argument that men are characterized by higher levels of abilities associated with community activity.

A second factor that can impact on community leadership training and skills is ethnicity. Ethnicity is an important factor that explains why black children in the United States are more likely than white children to live in low-income homes. ${ }^{39}$ Dei argues that for effectiveness in inclusive schooling in Ghana, educators and students should emphasize ways that people respond to ethnicity, gender and other forms of social difference, because such factors implicate the wider educational experience for the youth..$^{43}$ Experience in working with various different cultural groups according to $\mathrm{PhD}$ graduates in counselling and clinical psychologists, is important in predicting competence. ${ }^{44}$ Ethnicity is argued to moderate joint and unilateral decision making for 14-16 year olds in the United States. ${ }^{45}$ For example, for joint and unilateral youth decision making, variations in decision making had a stronger impact on mixed ethnically than in predominantly white communities (for Hispanic-American youth and for African-American youth). The negative impact of unilateral youth decision making was stronger in predominantly white communities. Similarly, ethnicity is a weak predictor of dropout, utilization and level of functioning among some ethnic groups in the United States. ${ }^{46}$ For example, ethnicity's effect on dropout and utilization have a larger effect on minority groups than Caucasian Americans.

A third factor that sometimes impacts on community competence training is age. Age is argued to mediate children's pre-academic skills and behaviour and are often considered the basis for placement and programming decisions. ${ }^{47}$ Age of a child affects what measures are possible to support the development of social competence. ${ }^{48}$ At preschool level for example, observation is argued to provide the best effect for developing social competence. Liberman ${ }^{49}$ also holds the conception that the aged compared to the younger population, are more successful in developing adaptive strategies to address life stresses. Younger populations are more vulnerable to threat and loss of management strategies to deal with stresses in life. ${ }^{49}$ Some studies have found that the diversity of rural livelihoods is key to measuring factors that impact on livelihoods as well as the ability of households to cope with such changes. ${ }^{50,51}$ According to Mutenje et al. ${ }^{52}$ people or communities that practice viable livelihoods, engage in formal employments, and/or practice mixed livelihoods are able to gain additional incomes that help the people to meet their livelihood demands and to overcome changes in their livelihoods.

In summary, training in community leadership skills may provide insights into improving community relationship. To explore this linkage, this study examines the development of Bui dam in Ghana. The Bui dam has inundated social and ecological resources, displaced communities, undermined livelihoods, and undermined social systems and infrastructure that form the foundation for effective community government mechanisms. ${ }^{53-54}$ Many studies have examined the impacts of dams and resettlement but, few have focused on changes in leadership capacity of communities nearby parks. This study will contribute to the discussions by examining the following research objectives:

a. Examine the impact of Bui Dam construction and resettlement on effectiveness of communities' role in managing Bui National Park

b. Investigate the impact of Bui Dam construction and resettlement on effectiveness of training in the management of Bui National Park

c. Explore whether resettlement, ethnicity, age, livelihood, and gender can mediate the impacts of Bui dam on effectiveness of training in the management of Bui National Park.

\section{Study area}

The study covers communities near BNP in Ghana perceived to be impacted by the construction of the Bui dam. BNP was formed to protect riverine vegetation around the Banda gorge, and protects eighty species of wildlife, including 305 hippopotamus considered red-listed by the International Union for Conservation of Nature (IUCN), and of global conservation concern. ${ }^{37,57,58}$ The park is the only protected area in Ghana that contains a large component of relatively undisturbed riverine forest associated with wooded savannah but also, one of the least developed parks in Ghana. ${ }^{37} \mathrm{BNP}$ the third largest PA in Ghana covers approximately $1812 \mathrm{~km}^{2},{ }^{37}$ and is located at $8^{\circ} 00^{\prime}$ $8^{\circ} 25^{\prime} \mathrm{N}, 2^{\circ} 15^{\prime}-2^{\circ} 30^{\prime} \mathrm{W}$. Ghana established Bui Power authority (BPA) 
in 2007 to oversee the construction of Bui dam. ${ }^{59,60}$ At full capacity, the Bui dam is expected to inundate $21 \%$ of Bui National Park, destroy $85 \mathrm{~km}$ of the bank of the Black Volta River (dammed at Bui), create 36 Islands and a $500 \mathrm{~km}$ reservoir shoreline; and destroy $50 \%$ of grassland, $20 \%$ of savannah woodland, and $25 \%$ of the water and riverine gallery forest. ${ }^{53,55}$

The study area is located in the Banda and Bole Districts of Brong Ahafo and Northern regions respectively. Bole is the district capital and the largest town in the Bole District. Bole District has a population of 61,593 and of $4000 \mathrm{sqkm} .{ }^{61}$ The Banda, Bamboi, and Bole Paramount Chiefs are responsible for villages within the study area. ${ }^{53}$ The Banda District Assembly has 45,000 people in 33 communities. The governing systems in the area are government institutions; chieftaincy systems; and Community Based Organizations (CBOs). CBOs include informal groups such as livelihood and cultural based groups that support socio-cultural networks in the area. But in many of the communities in the two districts, traditional leadership plays important roles in the management of people and to some extent, the regulation of basic livelihoods such as fishing and farming in the communities. Other stakeholders such as Bui National Park and Bui Power Authority are responsible for managing Bui National Park and Bui Power Authority respectively. Communities selected for the study (resettled and non-resettled) are impacted by the dam and also located in the two districts.

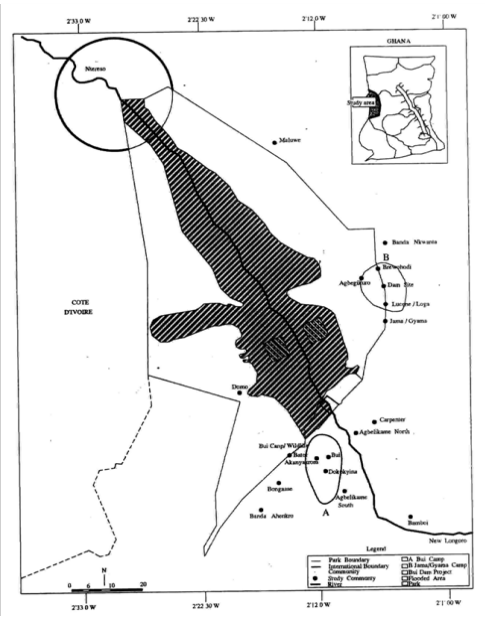

Figure I Map of Bui National Park with fringing villages, and inundated areas (ERM, ${ }^{53}$ Town and Country Planning, 2010)

Many communities in the region are multi-ethnic but, the dominant people in Bole district are Gonja or Mo, and Mo and Nafana

Table I List of villages around BNP inundated or isolated by the Bui Dam. ${ }^{53,61,62}$ in Tain District. ${ }^{61}$ Generally, livelihoods are linked to ethnic groups (Table 1). ${ }^{62,63}$ Although a variety of ethnic groups such as Gonja, Akan, Wala, Dagarti, and Lobi persist in the study area, ${ }^{53,63}$ the study placed much emphasis on the majority that is, Ewe, Nafana, and Mo. Community livelihoods include subsistence farming, fishing, hunting, wild produce collection, charcoal burning, wage labour, processing of cassava into garri for sale, and trading but, a few (Bator, Bui, Banda Nkwanta, Tainaboi, Mempeasem, and Agbelikame North and South) historically engaged in active fishing. ${ }^{53}$

\section{Methodology}

The study adopted a triangulation approach involving interviews with key informants, and household survey to provide insights into the issues being investigated. The use of triangulation for the study was necessary in order to check and establish validity in studies by analyzing a research question from multiple perspectives in order to arrive at consistency across data sources or approaches, and also provide an opportunity to uncover deeper meaning in the data. ${ }^{64,65}$ Information from key informant interviews provided inputs for the design of the household surveys. Both qualitative and quantitative methods were applied in the design and analysis of data for the study. The qualitative method was relevant in organizing inputs from key informants into themes to allow for a better analysis of issues investigated. Quantitative method of analysis through the use of different statistic was applied to analyse the different perceptions expressed by respondents.

The study forms part of a larger research project focusing on a multi-dimensional Canada-Africa Research and Learning Alliance seeking to address the challenges of reducing rural poverty and ensuring environmental sustainability through a focus on protected areas and adjacent communities in Canada, Tanzania and Ghana. ${ }^{66}$ This study explores processes to alleviate rural poverty, with a focus on dam and resettlement impacts on skills training in communities around Bui National Park (BNP). This study involved key informant interviews, document analysis, and household survey. Thirteen communities (Table 1) making up of a population of 9,627 (816 households) were selected for the study. Seven of the communities have been displaced by the Bui dam. The other six communities will not be relocated except, Bui Camp (Wildlife village) that is currently in the process of relocation. The resettled communities are located in two camps; Bui camp (containing Bator, Bui, Dokokyina), and Gyama camp (containing Dam site, Lucene, Brewohodi, and Agbegikro). The resettlement created a mix of adverse negative implications such as poor compensation for lands for farming and fishing, and loss of social and economic forms of livelihood available for the people in the communities nearby BNP.

\begin{tabular}{|c|c|c|c|c|c|c|}
\hline \multicolumn{7}{|l|}{ Banda District } \\
\hline Village & Ethnicity & Major livelihood & Resettled & Population & $\begin{array}{l}\text { Total } \\
\text { households }\end{array}$ & $\begin{array}{l}\text { Sampled } \\
\text { household }\end{array}$ \\
\hline Bui & Mo/Nafana & Farming & Yes & 297 & 42 & 25 \\
\hline Bator & Ewe & Fishing & Yes & 437 & 63 & 35 \\
\hline Dokokyina & Mo & Farming & Yes & 165 & 36 & 20 \\
\hline Bui Camp (Wildlife) & Multi-ethnic & $\begin{array}{l}\text { Mixed (fishing, farming, } \\
\text { employed by BNP) }\end{array}$ & No & 100 & 36 & 20 \\
\hline Banda Ahenkro & Nafana & Farming & No & 3323 & unknown & 50 \\
\hline Agbelikame South & Ewe & Fishing & No & 209 & 26 & 15 \\
\hline Bongaase & Nafana & - & No & 2797 & 347 & 50 \\
\hline \multicolumn{7}{|l|}{ Bole District } \\
\hline Lucene/Loga & agarti & Farming & Yes & 26 & 4 & 4 \\
\hline
\end{tabular}


Table Continued...

\begin{tabular}{|c|c|c|c|c|c|c|}
\hline Village & Ethnicity & Major livelihood & Resettled & Population & $\begin{array}{l}\text { Total } \\
\text { households }\end{array}$ & $\begin{array}{l}\text { Sampled } \\
\text { household }\end{array}$ \\
\hline Brewohodi & Dagarti & Farming & Yes & 48 & 10 & 5 \\
\hline Dam site & Ewe & Fishing & Yes & 36 & 6 & 5 \\
\hline Agbegikro & Ewe & Fishing & Yes & 107 & 22 & 15 \\
\hline Gyama & Mo & Farming & No & 1500 & 154 & 50 \\
\hline $\begin{array}{l}\text { Agbelikame } \\
\text { North }\end{array}$ & Ewe & Fishing & No & 702 & 70 & 35 \\
\hline Total & - & - & - & 9,627 & 816 & 329 \\
\hline
\end{tabular}

Selection of these villages was shaped by the need to compare the experiences of those villages who have been relocated with the experiences of villages that have not been relocated. For example, an impact assessment has indicated that Bui Dam will impact the Wildlife community; through the loss of some livelihoods such as fishing, charcoal burning, trading, and farming; loss of social facilities such as a church, clinic, and school; and the loss of traditional leadership..$^{53}$ The inclusion of the Wildlife, Bongaase, Gyama, Banda Ahenkro, Agbelikame North and South Wildlife villages in the sample was critical, because it will allow for a comparison with the relocated communities. Many of the communities in the study area have weak educational systems, and weak foundations in community competence such as, skills and competences to overcome stress in their livelihoods. ${ }^{53}$

\section{Key informant interviews}

Key informants for the study involved a total of twenty four (24) people from diverse groups; volunteers, women, young adults, aged, and researchers (of between 18-75years) who have undertaken some form of studies in the resettled communities around BNP. A key informant interview (use of a semi-structured interview) was preferred as an effective and flexible method, because it is an effective tool to probe for more information about the topic, ${ }^{67,68}$ and give the respondents freedom of self-expression and more creativity in providing detailed answers. ${ }^{69}$ Interviewees included eight traditional leaders and elders of the resettled communities, four from the livelihood groups (that is, traders, fishermen, fishmongers, and farmers), and representatives of BNP, BPA, school, church, District Assembly, and researchers (Table 2).

Table 2 List of key informants for the study

\begin{tabular}{|c|c|c|c|c|c|c|}
\hline $\begin{array}{l}\text { Respondent's } \\
\text { number }\end{array}$ & Town & Key Characteristics & $\begin{array}{l}\text { Respondent's } \\
\text { number }\end{array}$ & Town & Key Characteristics & $\begin{array}{l}\text { Case } \\
\text { Study }\end{array}$ \\
\hline V00I & Bui & Male & LOI3 & Bator & Fishing, Male, Youth & $\sqrt{ }$ \\
\hline V002 & Bator & Male, Elder & LOI4 & Bator & Fishmonger, Female, Youth & \\
\hline V003 & Dokokyina & Male, Elder & LOI5 & Dokokyina & Farmer, Male, Elder & $\sqrt{ }$ \\
\hline V004 & Wildlife & Male, Leader & LOI6 & Bator & Trader, Female, Youth & \\
\hline V005 & Dam site & Female, Elder & S0I7 & Bator & Teacher, Male, Elder & \\
\hline V006 & Brewohodi & Male, Elder & SOI8 & Bator & Catechist, Male, Elder & \\
\hline V007 & Lucene, & Male, Elder & SOI9 & Bongaase & Farmer, Male & $\sqrt{ }$ \\
\hline V008 & Agbegikro & Male, Chief & G020 & Wildlife & BNP, Male, Head & $\sqrt{ }$ \\
\hline L009 & Bator & Fisherman, Male, Youth & G02I & BPA camp & BPA, Male, Resettlement Officer & \\
\hline LOIO & Bator & $\begin{array}{l}\text { Fish monger, Female, } \\
\text { Youth }\end{array}$ & G022 & Bator & Assemblyman, Male, Youth & \\
\hline LOII & Dokokyina & Farmer, Male, Elder & R023 & Sunyani & \multicolumn{2}{|c|}{ Researcher A, Male, Lecturer/Planning Officer } \\
\hline LOI2 & Bator & Trader, Female, Youth & R024 & Sunyani & \multicolumn{2}{|c|}{$\begin{array}{l}\text { Researcher B, Female, Lecturer (with years of } \\
\text { research experience in communities near BNP) }\end{array}$} \\
\hline
\end{tabular}

Key informant interviews provided information on (1) the impact of Bui Dam construction and resettlement on effectiveness of communities' role in managing Bui National Park, (2) the impact of Bui Dam construction and resettlement on effectiveness of training in the management of Bui National Park, and (3) the role of resettlement, ethnicity, age, livelihoods, and gender in mediating the impacts of Bui dam on effectiveness of training in the management of Bui National Park. Responses were used as primary data, and also to inform the development of a household survey outlined below. Questions asked included how the people consider aspects of community leadership competence that have been changed by the Bui dam, whether any new forms of leadership have developed after the Bui dam, and whether people have received any training opportunities for adapting to the stresses in community leadership created after the Bui Dam construction and related resettlements. Key informant interviews served to complement survey findings, and also guide the presentation and interpretation of the results for the study.

Key informants were selected based on the specific roles they play in the society, and who were perceived to have some level of knowledge on issues being investigated. ${ }^{67,68,70}$ Snowballing was useful in suggesting other potential respondents through their personal network (such as friends, and people of the same thinking and orientation). ${ }^{71,72}$ Biases in snowballing were subjected to the following interventions; by obtaining a sizeable sample of potential respondents; ${ }^{73}$ relying on a variety of indirect sources such as informal meetings at social grounds, including markets, and community meetings to develop the respondents' base ${ }^{74}$ and reaching isolated groups such as women and young adults, and the aged. 


\section{Household survey}

The survey questionnaire was developed from a literature review and the key informant interviews. Questionnaire items focused on the impact of Bui Dam construction and resettlement on effectiveness of communities' role in managing Bui National Park, the impact of Bui Dam construction and resettlement on effectiveness of training in the management of Bui National Park, and the role of resettlement, ethnicity, age, and gender in mediating the impacts of Bui dam on effectiveness of training in the management of Bui National Park. A pilot study involving able and willing people was carried out in the resettled communities. Respondents were six researchers from academia; and ten people of at least one from each of the eight resettled communities around BNP. Respondents provided some reviews to the questions, and this helped to provide clarity and relevance of questions to the intended participants in the communities. Information from the pre-test was used to modify the household questionnaire to ensure that respondents easily understood the questions, and provided the required information. All statements were translated into the Akan language, a common language of the resettled communities. A translater was engaged to support the interviews, especially where informants could not speak or understand English or Akan (common to the researcher).

The sample involved participants representing households, randomly selected from an openly available village register that indicated housing units, and members of households. ${ }^{68}$ Households for the study represented people forming domestic social units sharing resources, specifically each of the following criteria: (1) share a meal a day, (2) share accommodation, and (3) share expenditure. ${ }^{75-79}$ The sample was comprised of 339 people (with $100 \%$ response rate), including adult male and female representatives of households (Table 1). Each household selected a representative to lead the household in providing responses to the questionnaire. The result was a sizeable number of females who responded to the questionnaire. In some cases as well, households were headed by single parents of whom a large number were females. Data was collected between 2013 and 2014 The sample was comprised of 339 people (with $100 \%$ response rate) which constituted at least $50 \%$ of the sampled population in most communities, including adult male and female heads of households which was a variable noted in the available village register (Table 1) (a sample of $50 \%$ is suitable for a population of a few hundred. ${ }^{80}$ The choice of sample size is also in line with Krejcie \& Morgan ${ }^{81}$ formula for determining the appropriate size (which was close to 291 for this study) as stated below was used:

$$
\begin{aligned}
& \mathrm{S}=\mathrm{X}^{2} \mathrm{NP}(1-\mathrm{P}) / \mathrm{d}^{2}(\mathrm{~N}-1)+\mathrm{X}^{2} \mathrm{P}(1-\mathrm{P}) \text { where } \\
& \mathrm{S}=\text { Required Sample size } \\
& \mathrm{X}=\mathrm{Z} \text { value (e.g. } 1.96 \text { for } 95 \% \text { confidence level) } \\
& \mathrm{N}=\text { Population Size } \\
& \mathrm{P}=\text { Population proportion (expressed as decimal) (assumed to be } \\
& 0.5(50 \%)
\end{aligned}
$$

$\mathrm{d}=$ Degree of accuracy $(5 \%)$, expressed as a proportion (.05); It is margin of error

Four trained Ghanaian research assistants who had at least a diploma level education in research methodology, conducted the surveys as well as the pilot study.

\section{Results and discussion}

\section{Institutions providing training}

In the resettlement plan, training was to be provided by many stakeholders but, coordinated by Bui Power Authority. Institutions that provided most of the training before and after the construction of the Bui dam (Table 3) were Bui National Park (BNP), followed by the Bui Power Authority (BPA). A substantial number of respondents (23\%) indicated that no training was provided before the dam construction. The district assemblies were among institutions that provided the least training before the dam. Students from institutions such as Sunyani Polytechnic, and University of Ghana, Legon also provided some forms of training for households before the dam was constructed. The

\begin{tabular}{|c|c|c|c|c|c|c|}
\hline \multirow[t]{3}{*}{ Institution } & \multicolumn{3}{|c|}{ Percent responding yes } & \multicolumn{3}{|c|}{ Percent responding yes } \\
\hline & \multicolumn{3}{|c|}{ Before bui dam } & \multicolumn{3}{|c|}{ After bui dam } \\
\hline & Yes \% & No response \% & Total\% & Yes\% & No response \% & Total\% \\
\hline Bui National Park (BNP) & 39.8 & 60.2 & 100 & 29.5 & 70.5 & 100 \\
\hline Bui Power Authority (BPA) & 22.2 & 77.8 & 100 & 13.4 & 86.6 & 100 \\
\hline Tain District Assembly (TDA) & 1.5 & 98.5 & 100 & 0 & 100 & 100 \\
\hline Banda Ahenkro District Assembly (BADA) & 2.4 & 97.6 & 100 & 3.6 & 96.4 & 100 \\
\hline Cooperatives & 4 & 96 & 100 & 8.5 & 91.5 & 100 \\
\hline Bole Bamboi District Assembly (BBDA) & 4.3 & 95.7 & 100 & 3.6 & 96.4 & 100 \\
\hline Environmental Protection Agency (EPA) & 0.9 & 99.1 & 100 & 0 & 100 & 100 \\
\hline Students & 7 & 93 & 100 & 7.6 & 92.4 & 100 \\
\hline No training provided & 23.4 & 76.6 & 100 & 33.4 & 66.6 & 100 \\
\hline
\end{tabular}
situation of training was not different after the dam, since BNP gave the highest number of training modules and followed by BPA. It was noted that cooperatives and students also led a number of training for households after the construction of Bui dam.

Table 3 Institution Providing Training opportunities before and after the construction of bui dam

Source, Field work, 2015 
Some key informants (e.g. V005) noted that other institutions such as the Ministry of Food and Agriculture (MOFA) provided some training opportunities before and after the Bui dam. A senior official of BPA (G016) noted that it is now important for institutions such as health, education, and district assemblies to provide some forms of institutional support for the resettled communities. Further, he added that it is now the responsibility of some state institutions to resource these facilities and also ensure their functionality for the resettled communities. For example, the resourcing and functioning of the school is the responsibility of the Ministry of Education, the clinic for the Ministry of Health, and the market for the District Assembly (G016). The results of the study show that the level of stakeholder involvement in training although had positive impact on the effectiveness of traditional leadership, it fell short of expectation, because a few institutions such as BPA was actively involved in training to meet potential dam impacts on livelihoods. Governmental institutions such as the District Assembly failed to provide the required support at the local level.

\section{Impact of bui dam on traditional leadership}

Traditional leadership is important to this research because in many of the dam impacted communities local governance is provided by traditional leadership. The actions and inactions of such leaders to a larger extent, impact on the development of skills and competences of people in their communities. Research questions 3 further explores traditional leadership. The impact of Bui Dam on traditional leadership is described in Table 4. Mean scores were higher for non relocated communities, as revealed in T-test findings in Table 4. This is explained by the fact that unlike many of the resettled communities that have lost titles to their ancestral lands and develop new emerging leader that compete in leadership at the local level, the non resettled communities still continue to practice and revere traditional leadership structures in the villages. In a way, the study results is similar to Bennett \& McDowell ${ }^{16}$ that argues that dam construction can lead to the loss of land and legal authority over land, a key source of power for indigenes as well as traditional leaders. The need to develop resettlement policies that uphold or strengthen land ownership for indigenous people as well as traditional leaders during shocks such as dam construction, is important in upholding the integrity of traditional leadership structures and power. For example, traditional leadership authority including the voice of the people can be lost through dam related impacts as did with the San Kaputura resettlement of communities near Etosha. ${ }^{18}$ When mean responses were compared by ethnicity before dam construction, some differences were apparent between each ethnic group, as follows (see ANOVA and Scheffe portions of Table 4):

i. Nafana mean scores were higher than for Ewe for 1 of 2 items

ii. Mo mean scores were higher than for Ewe for 1 of 2 items

iii. There was no difference between Nafana and Mo for either item.

Table 4 Impacts of Bui Dam on Effectiveness of Traditional Leadership by Relocate and Ethnicity: Before and After Dam Construction

\begin{tabular}{|c|c|c|c|c|c|c|c|c|c|c|c|}
\hline \multirow[t]{2}{*}{$\begin{array}{l}\text { Effectiveness } \\
\text { of } \\
\text { communities } \\
\text { in traditional } \\
\text { leadership }\end{array}$} & \multirow[t]{2}{*}{$\begin{array}{l}\text { Percent } \\
\text { responding } \\
\text { better }\end{array}$} & \multirow[t]{2}{*}{$\begin{array}{l}\text { Percent } \\
\text { responding } \\
\text { worse }\end{array}$} & \multirow[t]{2}{*}{$\begin{array}{l}\text { Mean*l } \\
\text { S.D. }\end{array}$} & \multicolumn{2}{|c|}{$\begin{array}{l}\text { Comparing } \\
\text { mean responses } \\
\text { for relocated vs } \\
\text { not relocated } \\
\text { communities }\end{array}$} & \multicolumn{5}{|c|}{$\begin{array}{l}\text { Comparing mean responses by } \\
\text { ethnicity }\end{array}$} & \multirow[b]{2}{*}{$\begin{array}{l}\text { Scheffe } \\
\text { Test*** }\end{array}$} \\
\hline & & & & Relocated & $\begin{array}{l}\text { Not } \\
\text { relocated }\end{array}$ & $\begin{array}{l}\text { t-test, } \\
\text { signif }\end{array}$ & $\begin{array}{l}\text { Nafana } \\
\text { (N) }\end{array}$ & $\begin{array}{l}\text { Mo } \\
\text { (M) }\end{array}$ & $\begin{array}{l}\text { Ewe } \\
\text { (E) }\end{array}$ & $\begin{array}{l}\text { Anova F, } \\
\text { Signif }\end{array}$ & \\
\hline Before Dam & 71.1 & 21.2 & $3.9 / 1.6$ & 2.27 & 4.6 & $\begin{array}{l}T=- \\
18.124 \\
P=<0.00 \mid\end{array}$ & 4.35 & 4.04 & 3.07 & $\begin{array}{l}F=18.229 \\
P=<0.001\end{array}$ & $\begin{array}{l}N-M=0.320 \\
N-E=<0.001 \\
M-E=<0.001\end{array}$ \\
\hline After Dam & 32.5 & 49.9 & $3.3 / 1.6$ & 3.92 & 3.02 & $\begin{array}{l}\mathrm{T}=4.984 \\
\mathrm{P}=<0.00 \mathrm{I}\end{array}$ & 3.12 & 3.3 & 3.55 & $\begin{array}{l}F=1.698 \\
P=0.185\end{array}$ & $\begin{array}{c}N-M=0.704 \\
N-E=0.185 \\
M-E=0.593\end{array}$ \\
\hline
\end{tabular}

Source, Field work, 2015

This trend is an indication of the fact that traditional leadership before the dam was mainly led by traditional leaders of the Nafana and Mo ethnic descent since these groups formed the custodians of lands in the Bui area. Ewes were in the minority and also held lands leased by the traditional leaders of Mo and Nafana ethnic groups. However, after dam construction there was no significant differences between ethnic groups. After the resettlement, many of the existing traditional leaders lost title to their lands through government appropriation of existing traditional lands. Control of the communities were also shifted to some extent, to the clan and family heads who do not necessarily directly provide traditional leadership before the resettlement. Ethnicity as argued by some literature ${ }^{46}$ can mediate the level of functioning in minority groups as did happen with the Bui study where ethnicity mediated the impacts of Bui Dam on the effectiveness of traditional leadership.

Analysis of means for livelihoods (Table 5) showed the following;
i. Farming was higher than fishing for 2 of 2 aspects
ii. Farming was higher than mixed for 1 of 2 items

iii. Fishing was higher than mixed for 1 of 2 aspects

ANOVA and Scheffe scores revealed the following trend;

a. Significant for effectiveness of traditional leadership after the dam

b. Significant for farming by fishing, and farming by mixed before the dam

Generally, livelihood opportunities after the dam have dwindled for people practicing farming and fishing livelihoods. New farmlands are small and unfertile, whilst fishing has shifted from river to lake fishing and as a result limited the number and scope of people who can presently engage in fishing activities. There is now the need for financial investment to purchase larger fishing boats, and out board motors before one can engage in lake fishing. Comparatively, people practicing mixed livelihoods are better able to balance the benefits from fishing and farming livelihoods to create an improvement in mixed livelihoods after the dam. As suggested by Mutenje et al. ${ }^{52}$ the practice of diversified rural livelihoods is an important step towards 
cushioning the impact of shocks such as dam since the practice of these mixed livelihoods such as formal employment, is able to add additional incomes to strengthen the economic gains of communities impacted by dam. For examples, communities that practice mixed livelihoods such as fishing and farming are effective in traditional leadership.
Table 6 examines the perceived effectiveness of traditional leadership, providing a comparison of responses before and after dam construction. For the total sample, there is a significant decline in perceived effectiveness after the dam. This pattern is repeated for most sub-samples: Nafana, Mo, and Ewe, and with villages that have not been relocated, but there was no change for relocated villages.

Table 5 Analysis of Impacts of Bui Dam on Effectiveness of Traditional Leadership by Livelihood: Before and After Dam Construction

\begin{tabular}{|c|c|c|c|c|c|c|c|c|}
\hline \multirow{3}{*}{$\begin{array}{l}\text { Effectiveness of Traditional } \\
\text { leadership before and after dam } \\
\text { construction }\end{array}$} & \multirow{2}{*}{\multicolumn{2}{|c|}{$\begin{array}{l}\text { Percent } \\
\text { Responding }\end{array}$}} & \multicolumn{6}{|c|}{ Comparing mean responses by livelihood } \\
\hline & & & \multirow[t]{2}{*}{$\begin{array}{l}\text { Mean/ } \\
\text { S.D }\end{array}$} & \multirow[t]{2}{*}{ Farming } & \multirow[t]{2}{*}{ Fishing } & \multirow[t]{2}{*}{ Mixed } & \multirow{2}{*}{$\begin{array}{l}\text { Anova } \\
\text { F, Signif. }\end{array}$} & \multirow[t]{2}{*}{ Scheffe test } \\
\hline & Better & Worse & & & & & & \\
\hline Before Dam & 71.1 & 21.2 & $3.9 / 1.6$ & 4.2 & 3.4 & 2.9 & $\begin{array}{l}F=13.016 \\
P=<0.001\end{array}$ & $\mathrm{Fa}-\mathrm{Fi}=<0.00 \mathrm{I}$ \\
\hline \multirow{4}{*}{ After Dam } & \multirow{4}{*}{32.5} & \multirow{4}{*}{49.9} & \multirow{4}{*}{$3.3 / 1.6$} & \multirow{4}{*}{3.4} & \multirow{4}{*}{3.2} & \multirow{4}{*}{3.5} & \multirow{4}{*}{$\begin{array}{l}F=0.820 \\
P=0.44 I\end{array}$} & $\begin{array}{l}\text { Fa-M }=0.002 \\
\text { Fi-M }=0.367\end{array}$ \\
\hline & & & & & & & & $\mathrm{Fa}-\mathrm{Fi}=0.54 \mathrm{I}$ \\
\hline & & & & & & & & Fa-M $=0.943$ \\
\hline & & & & & & & & Fi-M=0.668 \\
\hline
\end{tabular}

Source, Field work, 2015

Table 6 Summary of Impact of Dam Construction on Effectiveness of Traditional Leadership

\begin{tabular}{lllll}
\hline & \multicolumn{2}{l}{ Mean Effectiveness Score } & Paired t-test & Signif. \\
\cline { 2 - 3 } & \multicolumn{2}{c}{ Before dam } & After dam & \\
\hline Total Sample & 3.9 & 2.7 & $1 \mathrm{I} .577$ & $<0.00 \mathrm{I}$ \\
Relocated Villages & 2.3 & 2.1 & 1.145 & 0.253 \\
Not Relocated Villages & 4.6 & 3 & 15.207 & $<0.00 \mathrm{I}$ \\
Nafana & 4.3 & 2.9 & 8.867 & $<0 . .00 \mathrm{I}$ \\
Mo & 4 & 2.7 & 6.75 & $<0.00 \mathrm{I}$ \\
Ewe & 3.1 & 2.4 & 2.986 & 0.004 \\
\hline
\end{tabular}

Source, Field work, 2015

What is not clear in these findings is why effectiveness should decline in communities that have not been relocated. The study provides further backing to Robinson et al. ${ }^{34}$ because the Bui study shows that the effectiveness of training opportunities such as training in the right to manage resource in the Kunlog CREMA was significant in improving the effectiveness of traditional leadership for communities nearby dams. As in the case of the Bui study, effectiveness of traditional leadership can be achieved when training in livelihoods is conducted for communities to be impacted by dams and its associated resettlement of communities. But, grouping people into livelihoods groups, providing few inputs like seeds, fertilizer and fishing nets as part of livelihood programmes will not necessarily translate into marked successes and improvements in community livelihoods.

There is no significant relationship between effectiveness of communities in traditional leadership and gender or age. A community leader noted; "Take away a Chief's title deed to Land and landed property and you take away the respect, authority, and capability of the Chief to govern his subjects, and provide the needed spiritual and economic direction for his people" (V001). After the Bui dam, the reverence and respect for traditional leaders have diminished (V001); through loss of control over their people; reduction in power to maintain law and order; and loss of significance in the provision of spiritual and economic direction for the subjects. Key informants added that the authority of chiefs, especially the Bui Chief has been largely undermined by government's acquisition of lands through a government Legislative instrument, and also sown some forms of division amongst chiefs and settler communities-now resettled in Bui and Gyama resettlement camps (V001). It was noted that, community issues that were easily resolved in the past now end up in long litigations. Currently, the Chiefs are powerless in the control of new migrant workers who have flooded the fishing industry in the communities (V001). New leaders have emerged; because some youths are now breadwinners of their families; District Assemblies have now assumed more supervision over community activities; and social classes have naturally emerged and made some people more powerful and automatic leaders (G015).

This study is also similar to the findings of Teemacane Trust ${ }^{15}$ and International Rivers ${ }^{10}$ that argued that dams can destabilise communities and fracture community relationships and social structure forming the root of community governance arrangement, because the Bui study concludes that dam construction and associated resettlements can lead to the loss of authority of community members such as traditional leaders, and also create an emergence of new leaders in the community. 


\section{Impacts of bui dam on communities role in managing bui national park}

The following discussion examines how community members perceive dam impacts on governance processes regarding BNP (Research Questions 1 and 3). Overall responses were mixed, with percent responding "worse" similar to percent responding "better". Responses were generally same for community role in managing Bui National Park (BNP) before the Bui Dam construction. Mean score were better for nonrelocated before the Bui Dam. Before the dam construction, many of the communities nearby the park supported the management of BNP by performing rituals in the event of death in the park, educating the populace against hunting for game in the park, and also supporting the management of BNP to educate the masses on how to effectively manage wildlife-human conflicts. Skills training as concluded by Wallertein ${ }^{21}$ has a key role in the development of community empowerment for effective engagement in community actions, and therefore central to the findings of the Bui study. For example, communities that receive training in indigenous conservation ${ }^{16,28}$ can improve upon the effectiveness of traditional leadership as also cited by the Bui study.

Overall better responses for effectiveness of communities' role in managing Bui National Park after the dam, because people living near the dam can now ferry tourists for lake cruising for a fee. The development of the dam has in effect, made it possible for people in the communities to explore opportunities in tourism including boat cruising. This in effect, provides an important opportunity for people prepared to explore livelihood opportunities through tourism. The mix of impacts before and after the park is balanced for better contribution for lake cruising and ferrying of tourist after the dam and communities roles in the management of BNP before the dam. The developing of a mixed livelihood approach as also advanced by Ellis ${ }^{50}$ can help people or communities to practice viable livelihoods to support efforts to improve and contribute to leadership in their communities. The Bui study provides more insight into $\mathrm{IUCN}^{37}$ that argued that enhanced skills training in community leadership is an important step in helping communities to contribute to management authority, decision making, responsibility and ownership of protected areas. However, mean scores were better for nonrelocated under all aspects of effectiveness of communities in helping with the management of BNP, as revealed in T-test findings in Table 7. This is explained by the effect of the responses from the Wildlife community (a non resettled community, and also the community housing workers of BNP) on the other responding non resettled communities.

Table 7 Perceived Impacts of Bui Dam on Effectiveness of Communities' Role in Managing Bui National Park by Relocation and Ethnicity

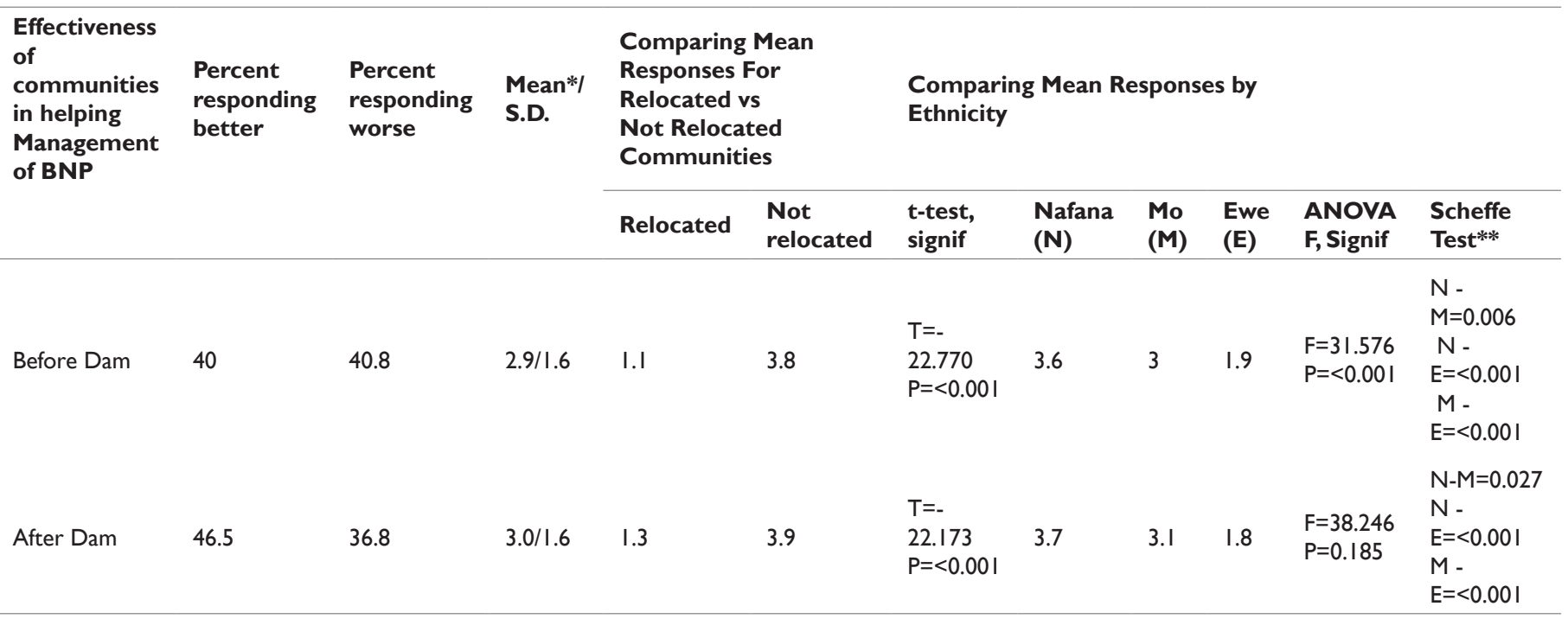

When comparing responses by ethnicity, before the dam, mean responses differed significantly (ANOVA and Scheffe portion of Table 7), as follows:
a. Nafana mean scores were higher than Mo
b. Nafana mean scores were higher than for Ewe
c. Mo mean scores were higher than for Ewe

The observed responses however, deviates from the expected since it is expected that Ewe communities should perform better since the Ewes (who are generally fishermen) were engaged in ferrying tourist, boat cruising, managing a rest stop, and selling of artefacts to support the management of Bui National Park before the construction of the Bui Dam. Similarly, when responses were compared by ethnicity after the dam, mean scores differed between all three ethnic groups (Table 7), as follows:
a. Nafana mean scores were higher than Mo
b. Nafana mean scores were higher than for Ewe
c. Mo mean scores were higher than for Ewe

Again, the Ewe community is expected to perform better unlike the observed trend since the Ewe communities partly ferry tourist and engage in lake cruising to support BNP and the livelihood activities of the fishermen.

Mean scores for livelihood under effectiveness of communities role in managing Bui National Park ranges between 2.88 and 3.04 (Table 8). Scores was as follows;

a. Farming mean scores were higher than fishing for 2 of 2 aspects

b. Farming mean scores were higher than for mixed livelihood for 1 of 2 items

c. Fishing mean scores were higher than mixed for 1 of 2 aspects

Again, it is difficult to explain the observed results of farming performing better than fishing since the farming communities are virtually not engaged in the management of BNP after the dam. Fishing is better than mixed since the fishing communities are still actively engaged in supporting the management of BNP through the provision of tourism services.

Analysis of livelihoods (ANOVA and Scheffe) revealed the following; 
a. significant for all aspects of livelihoods

b. significant for farming by fishing for 2 of 2 aspects

c. significant for farming by mixed for 1 of 2 aspects

d. significant for fishing by mixed for 1 of 3 items
Table 9 examines the perceived effectiveness of communities in managing Bui National Park, providing a comparison of responses before and after dam construction. For the total sample, there is a small but significant improvement in perceived effectiveness after the dam. This pattern is repeated with relocated villages, non relocated villages, and with the Mo ethnic group. In this analysis age and gender did not show any significant relationships.

Table 8 Perceived Impacts of Bui Dam on Effectiveness of Communities Role in Managing Bui National Park by Livelihood

\begin{tabular}{|c|c|c|c|c|c|c|c|c|}
\hline \multirow{2}{*}{$\begin{array}{l}\text { Effectiveness of } \\
\text { communities } \\
\text { role in managing } \\
\text { bui national park }\end{array}$} & \multicolumn{2}{|c|}{$\begin{array}{l}\text { Percent } \\
\text { responding }\end{array}$} & \multicolumn{6}{|c|}{$\begin{array}{l}\text { Comparing mean responses by } \\
\text { livelihood }\end{array}$} \\
\hline & Better & Worse & $\begin{array}{l}\text { Mean/ } \\
\text { S.D. }\end{array}$ & Farming & Fishing & Mixed & Anova F, Signif. & Scheffe test \\
\hline Before Dam & 40 & 40.8 & $2.9 / 1.6$ & 3.2 & 2.3 & 1.9 & $F=|5.539 P=<0.00|$ & $\begin{array}{l}\mathrm{Fa}-\mathrm{Fi}=<0.00 \mathrm{I} \\
\mathrm{Fa}-\mathrm{M}=0.002 \\
\mathrm{Fi}-\mathrm{M}=0.583\end{array}$ \\
\hline After Dam & 46.5 & 36.8 & $3.0 / 1.6$ & 3.4 & 2.3 & 3.6 & $F=20.528 P=<0.00 I$ & $\begin{array}{c}\mathrm{Fa}-\mathrm{Fi}=<0.00 \mathrm{I} \\
\mathrm{Fa}-\mathrm{M}=0.835 \\
\mathrm{Fi}-\mathrm{M}=0.002\end{array}$ \\
\hline
\end{tabular}

Source, Field work, 2015

Table 9 Summary of Impact of Dam Construction on Perceived Effectiveness of Community Role in Managing Bui National Park

\begin{tabular}{lllll}
\hline & \multicolumn{2}{l}{ Mean effectiveness score } & Paired t-test & \multirow{2}{*}{ Signif. } \\
\cline { 2 - 3 } & \multicolumn{2}{c}{ Before dam } & After dam & \\
\hline Total Sample & 2.9 & 3 & 3.02 & 0.003 \\
Relocated Villages & $\mathrm{I}$ & $\mathrm{I} .3$ & 2.634 & 0.01 \\
Not Relocated Villages & 3.8 & 3.9 & 1.96 & $0.05 \mathrm{I}$ \\
Nafana & 3.6 & 3.7 & 1.198 & 0.234 \\
Mo & 2.9 & 3.1 & 2.873 & 0.005 \\
Ewe & 1.9 & 1.9 & 0 & $\mathrm{I}$ \\
\hline
\end{tabular}

Source, Field work, 2015

Some informants added that, the Bator communities supported tourism at BNP: by providing river transport-hiring and paddling of canoes; providing local rest stop for tourists; and developing friendship and partnership with tourists whilst BNP collected gate fees and tour guide fees (V002). Bator community also helped to patrol some parts of BNP, report any illegal activities (including poaching) in the park to BNP officers and in return, receive access to conduct some regulated fishing in Park rivers (L009). Some key informants indicated that community inputs into the management of BNP, after Bui dam has diminished; because resettled communities, including Bator that previously supported the management of BNP, has been resettled farther away from BNP. Bator therefore, encounters difficulty in accessing park areas to offer some support in monitoring illegal activities in the park. More so, BNP has acquired two speed boats that ferry tourist for cruise tour and watch hippos that have migrated upstream, and increased wind action on lake that limits the suitability to use the relatively small boats of people in Bator village to support tourism (V002) and diminished the stakes of communities in tourism at BNP. The Bator community in particular, has lost all opportunities to support tourism, and contribute to the management of BNP (G017).

\section{Impacts of bui dam on effectiveness of training in the management of bui national park}

Before the dam, people living in communities near BNP were provided with some forms of training in the management of BNP.
Training was mainly provided by management and staff of BNP in aspects such as ways to conserve biodiversity, how to manage human-wildlife conflicts, and how to gain incomes through the provision of tourism services (G017). Responses on effectiveness of training of communities in helping with the management of BNP was worse for the majority of respondents. Training was few and in many communities did not take place. The effect of training therefore, in the management of Bui National Park is worse for many communities. The need to incorporate effective training in indigenous conservation practices for Bui communities impacted by the Bui Dam construction is paramount as some studies West et al. ${ }^{1}$ Baird $\&$ Dearden $^{30}$ Lockwood $^{31}$ Nelson $^{33}$ have identified that conservation training can lead to effective participation in governance of protected areas and also provide important hallmarks for communities to cope with socio-ecological changes such as species loss, poverty, and loss of community livelihoods and control of conservation efforts.

Mean scores was better for communities not relocated, as indicated by T-test scores (Table 10). This is also explained by the fact that the Bui dam construction has not in effect, affected the existing effectiveness of communities in the management of BNP. It is rather expected that training provided could have further heightened the effectiveness of the non resettled communities in the management of BNP. Both Nafana and Mo scores were higher than Ewe indicating a higher effectiveness of Nafana and Mo than Ewe in the effectiveness of training in the management of BNP after the construction of Bui dam. But, there was no difference, between Nafana and Mo in 
effectiveness of training in the management of BNP after the dam (ANOVA and Scheffe portions of Table 10). The impacts of Bui Dam were examined with respect to training in the aspects of relationship between community and BNP after the Bui dam, effectiveness of training in the management of BNP, and the mediating effects of ethnicity, age, gender and resettlement on Bui dam impacts on community relationship. These findings are outlined in the following sections.

There was no significant relationships by gender or by age.

Mean scores for livelihoods (Table 11) revealed that;

Table 10 Effectiveness of training of communities in the management of BNP by Relocate and Ethnicity i. Score for farming was higher than for fishing livelihood

ii. Score for mixed was higher than fishing and farming livelihoods

Analysis of ANOVA and Scheffe test showed the following;

i. Significant for livelihoods

ii. Significant for farming by fishing livelihoods

iii. Significant for fishing by mixed livelihoods

\begin{tabular}{|c|c|c|c|c|c|c|c|c|c|c|c|}
\hline & \multirow[t]{2}{*}{$\begin{array}{l}\text { Percent } \\
\text { responding } \\
\text { better }\end{array}$} & \multirow[t]{2}{*}{$\begin{array}{l}\text { Percent } \\
\text { responding } \\
\text { worse }\end{array}$} & \multirow[t]{2}{*}{$\begin{array}{l}\text { Mean*l } \\
\text { S.D. }\end{array}$} & \multicolumn{2}{|c|}{$\begin{array}{l}\text { Comparing Mean } \\
\text { Responses For } \\
\text { Relocated vs } \\
\text { Not Relocated } \\
\text { Communities }\end{array}$} & \multicolumn{4}{|c|}{$\begin{array}{l}\text { Comparing Mean Responses by } \\
\text { Ethnicity }\end{array}$} & \multirow[b]{2}{*}{$\begin{array}{l}\text { Anova F, } \\
\text { Signif }\end{array}$} & \multirow[b]{2}{*}{$\begin{array}{l}\text { Scheffe } \\
\text { Test*** }\end{array}$} \\
\hline & & & & Relocated & $\begin{array}{l}\text { Not } \\
\text { relocated }\end{array}$ & $\begin{array}{l}\text { t-test, } \\
\text { signif }\end{array}$ & $\begin{array}{l}\text { Nafana } \\
\text { (N) }\end{array}$ & $\begin{array}{l}\text { Mo } \\
(M)\end{array}$ & $\begin{array}{l}\text { Ewe } \\
\text { (E) }\end{array}$ & & \\
\hline \multirow[t]{2}{*}{$\begin{array}{l}\text { Effectiveness } \\
\text { of training of } \\
\text { communities } \\
\text { in helping } \\
\text { Management } \\
\text { of BNP }\end{array}$} & 32.8 & 53.2 & $2.4 / 1.6$ & 1.3 & 3.1 & $\begin{array}{l}T=- \\
I I .677 \\
P=<0.00 \mid\end{array}$ & 2.9 & 2.6 & 1.4 & $\begin{array}{l}F=25.404 \\
P=<0.00 I\end{array}$ & $\begin{array}{l}N- \\
M=0.235 \\
N- \\
E=<0.001\end{array}$ \\
\hline & & & & & & & & & & & $\begin{array}{l}M \\
-E=<0.001\end{array}$ \\
\hline
\end{tabular}

Table I I Effectiveness of Training of Communities in the Management of BNP by Livelihood

\begin{tabular}{|c|c|c|c|c|c|c|c|c|}
\hline \multicolumn{9}{|c|}{ Comparing mean responses by livelihood } \\
\hline & \multicolumn{2}{|c|}{ Percent Responding } & \multirow[t]{2}{*}{ Mean/S.D. } & \multirow[t]{2}{*}{ Farming } & \multirow[t]{2}{*}{ Fishing } & \multirow[t]{2}{*}{ Mixed } & \multirow[t]{2}{*}{ Anova F, Signif. } & \multirow[t]{2}{*}{ Scheffe test } \\
\hline & Better & Worse & & & & & & \\
\hline $\begin{array}{l}\text { Effectiveness } \\
\text { of Training of } \\
\text { Communities in } \\
\text { helping Management } \\
\text { of BNP }\end{array}$ & 32.8 & 53.2 & $2.5 / 1.6$ & 2.9 & 1.5 & 3.6 & $\begin{array}{l}\mathrm{F}=38.771 \\
\mathrm{P}=<0.001\end{array}$ & $\mathrm{Fa}-\mathrm{Fi}=<0.001$ \\
\hline
\end{tabular}

$\mathrm{Fa}-\mathrm{M}=0.112$

$\mathrm{Fi}-\mathrm{M}=<0.00$

Key informants noted that the contribution of communities (except Wildlife) to the management of BNP after training opportunities, were lower for all the communities. The informants explained that training opportunities in the management of the park, organized for the communities were few and did not necessarily explore how people in the communities could directly get involved in the management of BNP. The result of such training is low participation of communities to management of BNP, even after training was received: because training opportunities were few; training did not meet the needs of the various communities; worsening community livelihoods have made it difficult to provide support to management of BNP; and resettlement of communities have created difficulties in accessing park areas to offer support through tourism, and patrols as was previously undertaken by the Bator village (V003).

On the other hand, the Wildlife Village showed significant improvements in contribution to the management of BNP, after receiving training opportunities: because Wildlife village hosts staff and families of BNP; training provided such as, animal rescue, learning from experiences of the Akosombo dam, and dealing with threat such as, illegal activities provided for park staff suited the needs of BNP
(G015). Meanwhile the Bui study results differed from the findings of Kothari, ${ }^{35}$ West et al. ${ }^{1}$ IUCN, ${ }^{37}$ Nelson, ${ }^{33}$ Bennett $^{34}$ who identified that enhanced skills training in community leadership are able to contribute to the management of nearby protected areas by contributing to management authority, decision making, responsibility and ownership of community enforcement such as reduction in poaching and forest destruction in Kakum Conservation Area. The Bui study contracted these findings because training in park management for communities nearby Bui dam did not necessarily improve the effectiveness of dam and resettlement impacted communities to the management of nearby parks. The question, therefore, is to explore reasons for the failed impacts of training in leadership for communities nearby parks. Some reasons adduced for this trend is related to the failure to provide training in the needs assessment areas of communities, including training to directly impact on the livelihood needs of the people as well as training that promotes conservation of biodiversity. In this study, however, dam and resettlement impacts on community leadership led to the loss of opportunities (such as providing boats services and rest stops to tourist) that enabled communities nearby parks to contribute to the management of parks. 


\section{Conclusions}

The study concludes that effectiveness of traditional leadership in communities nearby park areas can be undermined by the construction of dams and related resettlements. In such cases of dam impacts, ethnicity can mediate impacts for nearby communities. Communities practicing mixed forms of livelihoods have the greater likelihood to withstand changes in effectiveness of traditional leadership after dams construction. Gender and age will not necessarily mediate the impacts of hydro dams on effectiveness of traditional leadership. Effectiveness of communities nearby parks, in helping with the management of national parks such as Bui National Park will not be significantly impacted by dam construction. However communities that have been relocated compared to non relocated communities will be worse impacted by dam construction. In this case of dam impacts, ethnicity provides some mediating impacts for the different ethnic groups nearby a dam. Communities practicing farming compared to fishing and mixed livelihoods are more effective in their contribution to the management of a park such as Bui National Park, especially after such communities have been impacted by dam construction.

In most communities, training in community competences will not result in positive impact on the effectiveness of communities in the management of a park e.g. BNP. In cases where training is provided after a dam construction, the impacts on the management of the park will be better for non relocated than relocated communities. Ethnicity will also mediate impacts of dams construction even after training has been provided. Mixed livelihood communities can better cope than farming and fishing livelihoods for communities that have been provided training in the phase of a dam construction. The need to provide practical hands-on training for communities in the phase of the construction of a hydro dam is critical in providing better coping strategies to deal with changes in traditional leadership. It is therefore recommended that plans to construct dams provide opportunities for developing, monitoring and evaluating proper training modules to support communities nearby the dam. Training schedules should cover the periods before, during and after the dam construction.

\section{Acknowledgments}

None.

\section{Conflict of interest}

Authors declare there is no conflict of interest.

\section{References}

1. West P, Igoe J, Brockington D. Parks and People: The Social Impact of Protected Areas. Annu Rev Anthropology. 2006;35:251-277.

2. International Monetary Fund. Medium-term National Development Policy Framework: Ghana Shared Growth and Development Agenda, 2010-2013. Washington DC, USA; 2012.

3. Reid D, Muruvi W. The Community Poverty Scan and Assets Based Ap proach to Poverty Reduction. University of Guelph, Guelph, Canada; 2011.

4. WCD. Water resources sector strategy: Strategic directions for World Bank engagement. Earthscan, London, USA; 2000.

5. Cernea M. For a New Economics of Resettlement: A Sociological Critique of the Compensation Principle. International Social Science Journal. 2003;55(175):37-47.

6. Nusser M. Technological Hydroscopes in Asia. In: NM, editor. Large Dams in Asia: Contestes Environments between Technological Hydroscapes and Social Resistance. Springer Dordrecht Heidelberg, New York, USA; 2014. p. 1-14.
7. Galipean BA, Ingman M, Tilt B. Dam-Induced Displacement and Agricultural Livelihoods in China's Mekong Basin. Human Ecology. 2013;41(3)4:37-446.

8. Hussein K. Livelihood Approaches Compared: A Multi-Agency Review of Current Practice. DFID, London, USA; 2002.

9. Bennett N, Lemelin H, Koster R, et al. A capital assets framework for appraising and building capacity for tourism development in aboriginal protected area gateway communities. Tourism Management. 2012;33:752-766.

10. International Rivers. Human Impacts of Dams. Rivers in Crisis. 2013.

11. Peter J. Dam history repeating. Dawson Creek: Infomart. 2013.

12. The World Bank. Involuntary Resettlement Sourcebook. The International Bank for Reconstruction and Development/The World Bank, Washington, USA; 2004.

13. Jovais E. Japan Removes Forst Large Dam. World Rivers Review. 2014;29(2):4-5.

14. Ross K. Mekong Transboundary Cooperation put to the Test. world Rivers Review. 2014;29(2):6.

15. Teemacane Trust. The Khwe of the Okavango Panhandle: The Past Life. Shakawe, SA; 2002.

16. Bennett O, McDowell C. Displaced: The human cost of development and displacement. Palgrave: Macmillan, IND; 2012.

17. le Roux W, White A. Voices of the San: Living in Southern Africa Today. Kwela Books, Cape Town, SA; 2004.

18. Paton D, McClure J, Burgelt P. Natural Hazard Resilience: The Role of Individual and household preparedness. In: D Johnston, editor. Disaster Resilience. Charles C. Thomas Ltd, Illinois, USA; 2006. p. 105-127.

19. Dzodzi N. Living in the shadow of the large dams: ling term responses of downstream and lakeside communities of Ghana's Volta River Project. Koninklijke Brill NV, Leiden, Netherlands; 2006.

20. Wallerstein N. Powerlessness, Empowerment, and Health: Implications for Health Promotion Programmes. American Sociological Review of Health Promotion. 1992;6(3):197-205.

21. Haines A, Sanders D, Lehmann U, et al. Achieving child survival goals: potential contribution of community health workers. The Lancet. 2007;369(9579):2121-2131.

22. Gregg C, Houghton B, Paton D, et al. Community preparedness for lava flows from Mauna Loa and Hualalin volvanoes. Journal of Volcanology. 2004;66(6):531-540.

23. Lasker R. Redefining readiness: Terrorism planning through the eyes of the public. The New York Academy of Medicine, New York, USA; 2004. p. 1-84.

24. Kopelman L. On the Evaluative Nature of Competency and Capacity of Judgement. International Journal of Law and Psychiatry. 1990;13:309-329.

25. Silberfeld M. The Mentally Incompetent Patient: A Perspective from the Competency Clinic. Health Law in Canada. 1990;11(2):33-37.

26. Wicclair M. Ethics and the Elderly. Oxford University Press, New York, USA; 1993.

27. Silberfeld M, Fish A. When the Mind Fails: A Guide to Dealing with Incompetency. University of Toronto Press, Toronto, Canada; 1994.

28. Brooks N. Vulnerability, risk and adaptation: A conceptual framework. Tyndall Centre for Climate Change Research. 2003. p. 38.

29. Smit B, Wandel J. Adaptation, adaptive capacity and vulnerability. Global Change Environment. 2006;16(3):282-292. 
30. Baird E, Dearden P. Biodiversity conservation and resource tenure regimes: A case study from Northern Cambodia. Environmental Management. 2003;32(5):541-550.

31. Lockwood M. Good governance for terrestrial protected area: A framework, principles and performance outcomes. Journal of Environmental Management. 2010;91(3):754-766.

32. Nelson F, Agrawal A. Patronage or Participation? Community-based Natural Resource Management Reform in Sub-Saharan Africa. Development and Change. 2008;39(4):557-585.

33. Nelson F. Introduction: The politics of natural resource governance in Africa. In Community rights, conservation and contested land: THe application of natural resource governance in Africa, Earthscan, London, USA; 2010. p. 3-31.

34. Robinson RW, Bennett N, king LA. "We Want Our Children to Grow Up to See These Animals;" Values and Protected Areas Governance in Canada, Ghana and Tanzania. Human Ecology. 2012;40(4):571-581.

35. Kothari A. Collaborative managed Protected Areas. In: Lockwood M, Kothari A. editors. Managing Protected Areas: A global scan. Earthscan, London, USA; 2006.

36. Borrini-Feyerabend G, Johnston J, Pansky D. Governance of protected areas. In: Lockwood M, Kothari A, editors. Managing Protected Areas: A global guide. Earthscan, London, USA; 2006. p. 116-145.

37. IUCN. Parks and Reserves in Ghana. Gland, Switzerland; 2010.

38. Greenburg MT, Lengua LJ, Cole JD, et al. Predicting Developmental Outcomes at School Entry Using Multiple-Risk Model: Four American Communities. Developmental Psychology. 1999;35(2):403-417.

39. Patterson CJ, Kupersmidt JB, Vaden NA. Income Level, Gender, Ethnicity, and Househod Composition as Predictors of Children's SchoolBased Competence. Child Development. 1990;61(2):485-494.

40. Folkman S, Lazarus RS. An Analysis of Coping in a Middle-Ages Community Sample. Journal of Health and Social Behavior. 1980;21(3):219-239.

41. Abukari Z, laser JA. Gender Differences in Academic Outcomes Among Ghanaian Youth: The Role of Protective and Risk Factors. Journal of Community Psychology. 2013;41(1):117-138.

42. Zanbar L, Itzhaky H. Community Activists' Competence: the Contributing Factors. Journal of Community Psychology. 2013;41(2):249-263.

43. Dei GJ. Dealing with differences: ethnicity and gender in the context of schooling in Ghana. International Journal of Educational Development. 2004;24(4):343-359.

44. Allison KW, Echemedia RJ, Crawford I, et al. Predicting Cultural Competence: Implications for Practice and Training. Professional Psychology: Research and Practice. 1996;27(4):386-393.

45. Lamborn SD, Dornbusch SM, Steinburg L. Ethnicity and Community Context as Moderators of the Relations between Family Decision Making and Adolescent Adjustment. Child Development 1996;67(2):283-301.

46. Maramba GG, Hall GC. Meta-Analyses of Ethnic Match as a Predictor of Dropout, Utilization, and Level of Functioning. Cultural Diversity and ethnic Minority Psychology. 2002;8(3):290-297.

47. La Paro KM, Pianta RC. Predicting Children' Competence in the Early School Years: A Meta-Analytic Review. Review of Educational Research. 2000;70(4):443-484.

48. Clikeman-Semrud M. Social Competence in Children. Spinger Science, New York, USA; 2007.

49. Lieberman MA. Adaptive Process in Late Life. In: Datan N, Ginsberg L, editors. Life-span Developmental psychology. Academic Press Inc, Newyork, USA; 1975. p. 135-160.
50. Ellis F. Household strategies and rural liveliholld diversification. Journal of Development Studies. 1998;35(1):1-38.

51. Bryceson D. The scamble in Africa: Reorienting rural livelihoods. world Development. 2002;30(5):725-739.

52. Mutenje G, Ortmann G, Ferrer S, et al. Rural livelihood diversity to manage economic shocks: Evidence from south-east Zimbabwe. Agrekon. 2010;49(3):338-357.

53. ERM. Environmental and Social Impact Assessment of the Bui Hydropower Project. Ministry if Energy/Bui Development Committee, Ghana; 2007.

54. Mettle M. Forced Resettlement in Ghana: THE Dam and the Affected People: The Bui Hydroelectric Project in Ghana. Ghana; 2011.

55. Ghana News Agency. Parliament adopt Intruments to establish 100 new new assemblies. Ghana News Agency, Ghana; 2012.

56. World Bank. Tanzania: Poverty, Growth, and Public Transfers-Options for a National Productive Safety Net Program. World Bank, Washington, USA; 2011.

57. Government of Ghana. Act 123: Ghana Administration of Lands 1961. Government of Ghana, Accra, Ghana; 1961.

58. Ofori-Amanfo R. Hippopotamun Census in Bui National Park. Ghana Wildlife Division, Accra, Ghana; 2005.

59. Government of Ghana. Act 740: Bui Power Authority Act 2007. Government of Ghana, Accra, Ghana; 2007.

60. Ampratwum-Mensah A. More power as Prez inaugurates Bui Dam. Graphic Online. 2013

61. Ghana Statistical Service. 2010 Population \& Housing Census. Ghana Statistical Service, Accra, Ghana; 2012. p. 1-15.

62. Stahl A. Making history in Banda: Anthropological visions of Africa's past. Cambridge University Press, Canbridge, UK; 2001.

63. Tain District Assembly. Tain District. 2012.

64. Thurmond VA. The point of triangulation. Journal of nursing scholarship. 2001;33(3):253-258

65. Heale R, Forbes D. Understanding triangulation in research. Evidence Based Nursing. 2013;16(4):98.

66. Protected Areas and Poverty Reduction. About PAPR. Protected Areas and Poverty Reduction (PAPR): Canada-Africa Research and Learning Alliance. 2010.

67. Creswell J. Research Design: Qualitative, Quantitative, and Mixed Methods Approaches. Sage Publications, London, USA; 2007.

68. Robson C. Real World Research. John Wiley \& Sons Ltd, West Sussex, $\mathrm{UK} ; 2011$.

69. Healey J. Statistics: A tool for social research. Wadsworth Publication Company, California, USA; 1998.

70. Creswell J. Research Design: Oualitative, Ouantitative, and Mixed Methods Approaches. Sage Publications, London, USA; 2003.

71. Henslin J. Studying deviance in four settings: Research experiences with cabbies, suicide, drug users, and abortionees. In: Douglas J, editor. Research in deviance. Random House, New York, USA; 1972. p. 35-70,

72. Biernacki P, Waldorf D. Snowballing sampling: Problems and techniques of chain referral sampling. Sociological Methods Research. 1981;10:141-163.

73. Atkinson R, Flint J. Accessing hidden and hard-toreach populations: Snowballing strategies. University of Surrey Social Research Update. 2001;33. 
74. Faugier J, Sarfeant M. Sampling hard to reach populations. Journal of Advance Nursing. 1997;26(4):790-797.

75. Bender DR. Refinement of the Concept of Household: Families, Co-Residence, and Domestic Functions. American Anthropologist, New Series. 1967;69(5):493-504.

76. Yanagisago S. Family and Household: The Analysis of Domestic Groups. Annual Review of Anthropology. 1979;8:161-205.

77. Wilk R, Miller S. Some Methodological Issues in Counting Communities and Households. Human Organization 1997;5 (1):64-70.
78. Davenport E, Higgins M, Somerville I. Narratives of new media in Scottish households: the evolution of a framework of inquiry. Journal of the American Society for Information Science. 2000;51(10):900-912.

79. Casimir GJ, Tobi H. Defining and using the concept of household: a systematic review. International Journal of Consumer Studies. 2011;35(5):498-506.

80. Nwana EO. Survey Sampling Methods - Classification and Types in Probability and Non-probability Sampling. Pub (03). 1981;42-8.

81. Krejcie RV, Morgan DW. Determining sample size for research activities. Educ psychol meas. 1970;30(3):607-610. 